\title{
1 Title: Spatial variability in the risk of death from COVID-19
}

\section{2 in $\mathbf{2 0}$ regions of Italy}

3 Authors: Kenji Mizumoto ${ }^{1,2,3 *}$, Sushma Dahal ${ }^{3 *}$, Gerardo Chowell $^{3 \text {, }}$

4 *Mizumoto and Dahal contributed equally

6 Affiliations:

$7{ }^{1}$ Graduate School of Advanced Integrated Studies in Human Survivability, Kyoto University

8 Yoshida-Nakaadachi-cho, Sakyo-ku, Kyoto, Japan

$9 \quad{ }^{2}$ Hakubi Center for Advanced Research, Kyoto University, Yoshidahonmachi, Sakyo-

10 ku,Kyoto, Japan;

$11{ }^{3}$ Department of Population Health Sciences, School of Public Health, Georgia State

12 University, Atlanta, Georgia, USA

13 Correspondence to:

14 G Chowell, Department of Population Health Sciences, School of Public Health, Georgia

15 State University, Atlanta, Georgia, USA

16 Tel: +1 4044139322 Fax: +1 4044132344

17 E-mail: gchowell@gsu.edu

\section{Article type:}

20 Original research

21 Word count:

22 Abstract: $193(\operatorname{Max} 200)$

23 Main: $2543(\operatorname{Max} 2500)$

\section{Number of references, tables and figures}

\section{Number of references: 28}

Number of tables and figures in main text: 1 table, 6 figures

28 Number of tables and figures in the supplement file: 2 tables and 2 figures 
Abstract

33 Objectives: Italy has been disproportionately affected by the COVID-19 pandemic,

34 becoming the nation with the third highest death toll in the world as of May $10^{\text {th }}, 2020$. We

35 analyzed the severity of COVID-19 pandemic across 20 Italian regions.

36 Method: We manually retrieved the daily cumulative numbers of laboratory-confirmed cases

37 and deaths attributed to COVID-19 across 20 Italian regions. For each region, we estimated

38 the crude case fatality ratio and time-delay adjusted case fatality ratio (aCFR). We then

39 assessed the association between aCFR and sociodemographic, health care and transmission

40 factors using multivariate regression analysis.

41 Results: The overall aCFR in Italy was estimated at 17.4\%. Lombardia exhibited the highest

42 aCFR (24.7\%) followed by Marche (19.3\%), Emilia Romagna (17.7\%) and Liguria (17.6\%).

43 Our aCFR estimate was greater than $10 \%$ for 12 regions. Our aCFR estimates were

44 statistically associated with population density and cumulative morbidity rate in a

45 multivariate analysis.

46 Conclusion: Our aCFR estimates for overall Italy and for 7 out of 20 regions exceeded those

47 reported for the most affected region in China. Our findings highlight the importance of 48 social distancing to suppress incidence and reduce the death risk by preventing saturating the 49 health care system.

51 Keywords: COVID-19, Italy, regions, time-delay adjusted CFR, 2020 
medRxiv preprint doi: https://doi.org/10.1101/2020.04.01.20049668; this version posted May 18, 2020. The copyright holder for this preprint (which was not certified by peer review) is the author/funder, who has granted medRxiv a license to display the preprint in perpetuity.

It is made available under a CC-BY-NC-ND 4.0 International license .

\section{Introduction}

54 Since the first COVID-19 cases in Wuhan, China, the virus rapidly spread throughout China,

55 and subsequently spread across all continents of the world. As of May 10, 2020 a total of

56 3,917,366 confirmed COVID-19 cases including 274,361 deaths have been recorded globally

57 with 215 countries/territories/areas reporting variable disease growth rates. ${ }^{1}$ Moreover, the

58 US has reported the highest number of cases (31.8\%) and the highest death toll $(27.5 \%){ }^{1}$

59

60 The severity impact of any pandemic situation like COVID-19 largely depends on the

61 transmission rate of the disease, the capacity of the health care system, and the spectrum of

62 clinical severity which is tied to socio-demographic factors (age, gender) and the underlying

63 prevalence of comorbidities in the population. ${ }^{2}$ A better understanding of the expected influx

64 of severe patients to the health care system during the coronavirus pandemic in different

65 areas of the world is key to anticipate medical resources such as ICU units and ventilators

66 which are critically needed to save the lives of severely ill patients. ${ }^{2-4}$

68 The case fatality ratio (CFR) is one of the most important epidemiological metrics to quantify

69 the clinical severity of emerging infectious diseases such as COVID-19. ${ }^{3,5}$ So far, several

70 studies have attempted to elucidate the CFR for different population segments and

71 geographic regions particularly based on epidemiological data from China. ${ }^{7-9}$ However, there

72 is still a scarcity of studies carefully estimating the severity of the COVID-19 pandemic in

73 populations outside China. Accumulating epidemiological data indicates that the CFR varies

74 by geographical location, intensity of transmission, characteristics of patients such as age,

75 sex, and comorbidity status. ${ }^{8}$ For example, the time-delay adjusted CFR (aCFR) for Wuhan

76 was estimated at $12.2 \%$ compared to $4.2 \%$ for Hubei province excluding Wuhan and $0.9 \%$ in

77 China excluding Hubei province. ${ }^{6}$ While rough differences in severity of the pandemic in 
medRxiv preprint doi: https://doi.org/10.1101/2020.04.01.20049668; this version posted May 18, 2020. The copyright holder for this preprint

(which was not certified by peer review) is the author/funder, who has granted medRxiv a license to display the preprint in perpetuity.

It is made available under a CC-BY-NC-ND 4.0 International license .

78 different countries have been highlighted, ${ }^{9}$ there is a need to quantify spatial variability in

79 CFR and investigate how this variability is influenced by population factors and the

80 characteristics of the health care system.

81

82 At the time of writing, Italy was exhibiting an alarming effect of the COVID-19 pandemic

83 with the third highest death toll after the US and the $\mathrm{UK}^{1}$ but the estimates of the CFR that

84 carefully account for the delay from onset of symptoms to death are not yet available. In this

85 study we provide estimates of the COVID-19 CFR across 20 Italian regions by linking

86 statistical methods with publicly available daily series of confirmed cases and deaths. We

87 also investigated the association between aCFR and sociodemographic, health care and

88 transmission related factors using regression analysis.

\section{Methods}

$90 \quad$ Study setting

91 Italy is located in Southern Europe and there are 20 administrative regions in the country:

92 Lombardia, Emilia Romagna, Veneto, Piemonte, Marche, Toscana, Lazio, Campania,

93 Liguria, Friuli V.G., Sicilia, Puglia, Umbria, Molise, Trentino-Alto Adige, Abruzzo, Valle

94 d'Aosta, Sardegna, Calabria, Basilicata. ${ }^{10}$ For this study we have conducted a separate

95 analysis for Trento and Bolzano provinces within Trentino-Alto Adige region based on data

96 availability.

97

98 The first two confirmed cases of COVID-19 in Italy were reported on $31^{\text {st }}$ January 2020 and

99 had a travel history to Wuhan, China. The third case was not confirmed until February 7 and

100 on February 22, the cumulative case count reached 9. Subsequently, the incidence trajectory 
medRxiv preprint doi: https://doi.org/10.1101/2020.04.01.20049668; this version posted May 18, 2020. The copyright holder for this preprint

(which was not certified by peer review) is the author/funder, who has granted medRxiv a license to display the preprint in perpetuity.

It is made available under a CC-BY-NC-ND 4.0 International license .

101 rapidly increased for about 8 weeks and then gradually started to decline ${ }^{11}$ with daily reported

102 incidence below 2000 cases since 30 April $2020 .^{12}$

\section{Data sources}

104 We manually retrieved the daily cumulative numbers of laboratory confirmed COVID-19

105 cases and deaths stratified for 21 Italian regions from the daily released report of the Ministry

106 of Health of Italy from March 2 to May 10, 2020. ${ }^{12}$

107 For each region, we retrieved major socio-demographic and healthcare variables to explore

108 their influence on the estimated COVID-19 aCFR across areas. We also incorporated the total

109 number of tests, the total number of tests per population size and two transmission-related

110 metrics: the cumulative morbidity (cumulative cases) and the cumulative morbidity rate

111 calculated as the cumulative cases divided by the local population size. These variables are

112 summarized in Table S2.

113 Statistical analysis

114 The crude CFR (cCFR) is defined as the number of cumulative deaths divided by the number

115 of cumulative cases at a specific point in time. For the estimation of CFR in real time, we

116 employed the delay from hospitalization to death, $h_{s}$, which is assumed to be given by $h_{s}=$

$117 H(\mathrm{~s})-H(\mathrm{~s}-1)$ for $s>0$ where $H(\mathrm{~s})$ is a cumulative density function of the delay from

118 hospitalization to death and follows a gamma distribution with mean 10.1 days and SD 5.4

119 days, obtained from the previously published paper. ${ }^{6}$ Let $\pi_{a, t i}$ be the time-delay adjusted case

120 fatality ratio on reported day $\mathrm{t}_{i}$ in area $a$, the likelihood function of the estimate $\pi_{a, t i}$ is 


$$
\begin{aligned}
& L\left(\pi_{a, t_{i}} ; c_{a, t}, D_{a, t i}\right) \\
&=\prod_{t_{i}}\left(\sum_{\begin{array}{c}
t=1 \\
D_{a, t_{i}}
\end{array}}^{t_{i}} c_{a, t}\right)\left(\pi_{a, t_{i}} \frac{\sum_{t=2}^{t_{i}} \sum_{s=1}^{t-1} c_{a, t-s} h_{s}}{\sum_{t=1}^{t_{i}} c_{a, t}}\right)^{D_{a, t_{i}}}(1 \\
&\left.-\pi_{a, t_{i}} \frac{\sum_{t=2}^{t_{i}} \sum_{s=1}^{t-1} c_{a, t-s} h_{s}}{\sum_{t=1}^{t_{i}} c_{a, t}}\right)^{\sum_{t=1}^{t i} c_{a, t}-D_{a, t_{i}}}
\end{aligned}
$$

121 where $\mathrm{c}_{a, t}$ represents the number of new cases with reported day $\mathrm{t}$ in area $\mathrm{a}$, and $\mathrm{D}_{a, t i}$ is the

122 cumulative number of deaths until reported day $\mathrm{t}_{i}$ in area $a \cdot{ }^{13,14}$ Among the cumulative cases

123 with reported day $t$ in area a, $\mathrm{D}_{a, t i}$ have died and the remainder have survived the infection.

124 The contribution of those who have died with biased death risk is shown in the middle

125 parenthetical term and the contribution of survivors is presented in the right parenthetical

126 term. We assume that $\mathrm{D}_{a, t i}$ is the result of the binomial sampling process with probability $\pi_{a, t i}$.

127 We estimated model parameters using a Monte Carlo Markov Chain (MCMC) method in a

128 Bayesian framework. Posterior distributions of the model parameters were estimated by

129 sampling from the three Markov chains. Convergence of MCMC chains were evaluated using

130 the potential scale reduction statistic. ${ }^{15,16}$ Estimates and $95 \%$ credibility intervals for these

131 estimates are based on the posterior probability distribution of each parameter and based on

132 the samples drawn from the posterior distributions.

133 We employed multiple linear regression models to evaluate the association between regional

134 level aCFR estimates attributable to COVID-19. A detailed description is provided in the 135 supplement.

136 All statistical analyses were conducted in R version 3.6.1 (R Foundation for Statistical

137 Computing, Vienna, Austria). 
medRxiv preprint doi: https://doi.org/10.1101/2020.04.01.20049668; this version posted May 18, 2020. The copyright holder for this preprint (which was not certified by peer review) is the author/funder, who has granted medRxiv a license to display the preprint in perpetuity.

It is made available under a CC-BY-NC-ND 4.0 International license.

140 As of May 10, a total of 219,070 cases and 30,560 deaths due to COVID-19 have been

141 reported in Italy. Moreover, the Lombardia region has reported the highest number of cases

142 at 81,507 (32.7\%) and deaths at 14,986 (49.0\%) followed by Emilia Romagna with 26796

143 (12.2\%) cases and 3845 (12.6\%) deaths, and Piemonte with 28665 (13.1\%) cases and 3367

$144(11.0 \%)$ deaths.

146 Figure 1 and 2 display the curves of cumulative cases and cumulative deaths in (A)

147 Lombardia, (B) Emilia Romagna, (C) Veneto, (D) Piemonte, (E) Marche, (F) Toscana, (G)

148 Lazio, (H) Campania, (I) Liguria, (J) Friuli V.G., (K) Sicilia, (L) Puglia, (M) Umbria, (N)

149 Molise, (O) Trento, (P) Abruzzo, (Q) Bolzano, (R) Valle d'Aosta, (S) Sardegna, (T) Calabria,

150 (U) Basilicata, and (V) National, over time, respectively. Cumulative cases and cumulative

151 deaths increased rapidly in the Lombardia, Emilia Romagna, and Pimonte regions.

153 Figure 3 and 4 illustrate observed and model based posterior estimates of the cCFR and aCFR

154 in different regions in Italy. Except for the initial days (first 5 days) our model based cCFR

155 fitted the observed data well. For the aCFR, our model based posterior estimates are higher

156 than the observed cCFR. Across most of the regions of Italy, the differences between cCRF

157 and aCFR are greater in the initial 3-4 weeks and then slowly declining difference in the later

158 stage of the epidemic. For the most affected Lombardia region, the aCFR was stable at

159 highest point (100\%) during the first 7 days (considering March 1st as day 1) and rapidly

160 declined to $50 \%$ by day 15 and thereafter exhibited a gradual decline (about $25 \%$ by day 40 ).

161 We saw a similar trend for Emilia Romagna and for the national level. For other regions such

162 as Veneto, Marche the initial stable period was absent. For Toscana, Campania, Sicilia,

163 Umbria, Molise, and Basilicata, the cCFR and aCFR varied slightly during the initial phase of

164 epidemic. There was an overall downward trend of aCFR across all the regions of Italy. 
medRxiv preprint doi: https://doi.org/10.1101/2020.04.01.20049668; this version posted May 18, 2020. The copyright holder for this preprint (which was not certified by peer review) is the author/funder, who has granted medRxiv a license to display the preprint in perpetuity.

It is made available under a CC-BY-NC-ND 4.0 International license .

166 A summary of the aCFR, range of median estimates and cCFR of COVID-19 across 20

167 regions of Italy are presented in Table 1. Lombardia had the highest aCFR of $24.7 \%$ (95\%

168 credible interval: 24.4, 25.1] followed by Marche (19.3\%) [95\% CrI: 18.2, 20.5], Emilia

169 Romagna (17.7\%) [95\% CrI: 17.2, 18.3] and the Liguria (17.6\%) [95\% CrI: 16.8, 18.6]

170 (Table 1, figure 3). The Umbria region exhibited the lowest aCFR (5.2\%) [95\% CrI: 4.0, 6.4]

171 (Table 1).

172

173 Regions with higher population density and those with a higher cumulative morbidity rate

174 tended to exhibit higher aCFR estimates. These two predictors explained $58 \%$ variability

175 (Adjusted $\left.\mathrm{R}^{2}=0.58\right)$ in the severity of pandemic across the Italian regions $(\mathrm{P}<0.05)$ (Table

176 S1). Figure 7 displays the geographic distribution of the aCFR, population density per square

$177 \mathrm{~km}$, and the cumulative morbidity rate across 20 Italian regions. The scatter plots and the

178 correlation coefficients between aCFR and the variables included in the regression analysis

179 are shown in Figure S1. Figure S2 displays the scatter plot of cumulative cases per total tests

180 and cumulative morbidity rate for different regions of Italy. Because cumulative morbidity

181 per total number of tests was statistically associated with cumulative morbidity rate, it was

182 excluded due to multicollinearity ( $\mathrm{p}$ value $<0.00, \mathrm{r}=0.85$ ) (Figure $\mathrm{S} 2$ ).

183

184 Discussion

185 In this paper, we have estimated the time delay adjusted case fatality ratio of COVID-19 for

18620 regions of Italy. Our latest estimate of aCFR in Italy varied substantially across regions

187 with the highest value in the Lombardia region (24.7\%) in the Northwest and the lowest in

188 the Umbria region (5.2\%) in the Central Italy. The aCFR estimate for the national level was

$18917.4 \%$. A total of 12 administrative regions had aCFR estimates greater than $10 \%$. Our results 
medRxiv preprint doi: https://doi.org/10.1101/2020.04.01.20049668; this version posted May 18, 2020. The copyright holder for this preprint

190 emphasize the need to generate real-time regional severity estimates to focus mitigation

191 efforts and allocate medical resources that help ameliorate the burden on strained or

192 overwhelmed health care infrastructures.

194 We found that the regions in Northern Italy were the most affected compared to regions in

195 Southern Italy including Islands. The aCFR estimates across 7 administrative regions:

196 Lombardia, Emilia Romagna, Piemonte, Marche, Liguria, Abruzzo, and Valle d'Aosta were

197 higher than the aCFR estimates for Wuhan (12.2\%) (6) and Korea (1.4\%). ${ }^{17}$

199 Results of the multivariate analysis indicate that population density and cumulative morbidity

200 rate are statistically associated with aCFR in Italy, which underscore the importance of social

201 distancing and the need to suppress the incidence curve in order to avoid saturating the health

202 care system and reduce the death risk. We found a statistically significant association of

203 cumulative morbidity per total number of tests and cumulative morbidity rate. This is likely

204 attributable to the different testing strategies implemented during the early transmission phase

205 and in the later phase of epidemic. ${ }^{18}$

207 When we compare the aCFR of the most affected regions in Italy and China, the estimate for

208 Italy is about twice the estimate for China $(24.7 \%$ vs $12.2 \%) .{ }^{6}$ This difference may be partly

209 explained by the demographic structure of the two countries as suggested in a previous

210 study, ${ }^{18}$ namely Italy has an older population compared to China. In 2019, approximately

$21123 \%$ of the Italian population was 65 years and older $^{18}$ compared to $12.6 \%$ in China. ${ }^{19}$ Other

212 factors behind the differences in the CFR estimates could be associated with the timing and

213 intensity of public health and social measures such as 'lockdown' measures. In Wuhan, China

214 aggressive lockdown measures were put in place for about 3 weeks after the report of first 
medRxiv preprint doi: https://doi.org/10.1101/2020.04.01.20049668; this version posted May 18, 2020. The copyright holder for this preprint (which was not certified by peer review) is the author/funder, who has granted medRxiv a license to display the preprint in perpetuity.

It is made available under a CC-BY-NC-ND 4.0 International license .

215 COVID-19 case. $^{20}$ In Italy, Northern provinces were put under lockdowns only 5 weeks after

216 the first recorded cases. Yet, the extent and guidelines of the lockdown were not clearly

217 defined. ${ }^{21}$ Similarly, different testing strategies may have also influenced differences in CFR.

218 Likewise, in the early phase of epidemic, there was an extensive testing strategy in Italy that

219 included both symptomatic cases and their asymptomatic contacts but later more strict testing

220 policies prioritized more severe suspected cases requiring hospitalization. ${ }^{18}$

222 In our study, as the epidemic progressed, we saw a downward trend in the aCFR for most of

223 the regions in Italy. For Lombardia, Emilia Romagna and for national level, there was also an

224 initial phase with steady high-level CFR which was relatively longer for Lombardia region

225 compared to Emilia Romagna. A previous study on COVID-19 using data from China has

226 also found the declining trend of aCFR for Hubei province excluding Wuhan. ${ }^{6}$ This trend was

227 also reported for the 2015 MERS outbreak in South Korea in which the risk of death was

228 significantly associated with older age and underlying health condition. ${ }^{22}$ In the early phase

229 of the outbreak of an emerging infectious disease like MERS and COVID-19, the detection

230 rate of mildly symptomatic cases is low and only patients who have serious conditions are

231 confirmed due to hospitalization as happened in Wuhan ${ }^{23,6}$ and South Korea. ${ }^{22}$ However the

232 downward trend of CFR in the later phase of epidemic suggests both an improvement in

233 epidemiologic surveillance and a decline in the proportion of vulnerable patients. ${ }^{6}$ Because of

234 the decline in the proportion of vulnerable patients and an increased detection of mildly

235 symptomatic cases, the epidemic might be prolonged unless strict social/physical distancing

236 measures are applied. ${ }^{6}$

237 Our findings underscore the utility of real-time severity estimates to guide the urgent

238 allocation medical resources in highly affected regions and the appropriate planning and

239 supplies procurement in the other regions of Italy with a focus on medical care delivery to the 
medRxiv preprint doi: https://doi.org/10.1101/2020.04.01.20049668; this version posted May 18, 2020. The copyright holder for this preprint

240 most vulnerable populations with the highest risk of poorer disease outcomes due to COVID-

24119 such as patients categorized as critical, the elderly, and those with multiple comorbidities

242 including cardiovascular disease, hypertension, and diabetes. ${ }^{8}$ Similarly, social distancing

243 measures are critical to prevent the health care system from overloading to a breaking point.

244 After a lockdown that lasted for about two months throughout the country, Italy started to

245 ease movement restrictions on May 4, 2020. However, this should be conducted cautiously

246 by putting in place the necessary infrastructure for tracing, testing, isolation and treatment in

247 place to reduce the likelihood that the disease resurges. ${ }^{24}$

249 Our study is not exempted from limitations. The preferential ascertainment of severe cases

250 bias in COVID-19 may have spuriously increased our estimate of CFR, ${ }^{25}$ which is a frequent

251 caveat in this type of studies. ${ }^{26,27}$ Similarly, for a disease like COVID-19 where transmission

252 is characterized by a rapid growth phase in case incidence, but the infection-death time is

253 long (ranges from 2 to 8 weeks), ${ }^{8}$ our CFR estimate could have been affected by delayed

254 reporting bias. ${ }^{25,28}$ Similarly, our data on number of cases reflects the date of reporting and

255 not the date of onset of illness.

\section{Conclusion}

258 The risk of death due to COVID-19 in Italy was estimated at $17.4 \%$ with varying rates across

25920 regions. Our estimates of time delay adjusted CFR was as high as $24.7 \%$ in Lombardia, in

260 Northwest Italy and as low as 5.2\% in the Umbria region, located in Central Italy.

261 Importantly, 12 out of the 20 regions exhibited aCFR values greater than $10 \%$ and the

262 estimates for 7 regions exceeded previous estimates for the most affected regions in China

263 and Korea. Our findings underscore the importance of social distancing to mitigate the 
medRxiv preprint doi: https://doi.org/10.1101/2020.04.01.20049668; this version posted May 18, 2020. The copyright holder for this preprint

(which was not certified by peer review) is the author/funder, who has granted medRxiv a license to display the preprint in perpetuity.

It is made available under a CC-BY-NC-ND 4.0 International license .

264 incidence curve to reduce the risk of death from COVID-19, which we found to be

265 significantly associated with the cumulative morbidity rates and population density.

266

267 Acknowledgments

268 KM acknowledges support from the Japan Society for the Promotion of Science (JSPS)

269 KAKENHI (Grant Number 18K17368 and 20H03940) and from the Leading Initiative for

270 Excellent Young Researchers from the Ministry of Education, Culture, Sport, Science \&

271 Technology of Japan. GC acknowledges support from NSF grant 1414374 as part of the joint

272 NSF-NIH-USDA Ecology and Evolution of Infectious Diseases program.

273

274 Conflict of interest

275 The authors declare no conflicts of interest.

276 Additional files

277 Additional file 1:

278 Appendix. Table S1. Multivariate models of time-adjusted case fatality ratio as a function of 279 major socio-demographic, and healthcare variables for 21 regions in Italy. Table S2. The

280 range of major socio-demographic, and healthcare variables for 21 regions in Italy used in

281 our analyses (linear regression). Figure S1. Scatter plots of time-delay adjusted CFR and

282 other variables with correlation coefficients. Figure S2. Scatter plot of cumulative morbidity

283 rate and cumulative cases per total tests with correlation coefficients.

\section{References}

286 1. WHO. Coronavirus disease 2019 (COVID-19): Situation report 111. 10 May 2020. 
medRxiv preprint doi: https://doi.org/10.1101/2020.04.01.20049668; this version posted May 18, 2020. The copyright holder for this preprint (which was not certified by peer review) is the author/funder, who has granted medRxiv a license to display the preprint in perpetuity.

It is made available under a CC-BY-NC-ND 4.0 International license .

2. Lipsitch M, Swerdlow DL, Finelli L. Defining the epidemiology of Covid-19—studies needed. N Engl J Med. 2020.

3. Reich NG, Lessler J, Cummings DA, Brookmeyer R. Estimating absolute and relative case fatality ratios from infectious disease surveillance data. Biometrics. 2012;68(2):598606.

4. Wu JT, Leung K, Bushman M, Kishore N, Niehus R, de Salazar PM, et al. Estimating clinical severity of COVID-19 from the transmission dynamics in Wuhan, China. Nature Med. 2020. doi: 10.1038/s41591-020-0822-7.

5. Ghani A, Donnelly C, Cox D, Griffin J, Fraser C, Lam T, et al. Methods for estimating the case fatality ratio for a novel, emerging infectious disease. Am. J. Epidemiol. 2005;162(5):479-86.

6. Mizumoto K, Chowell G. Estimating Risk for Death from 2019 Novel Coronavirus Disease, China, January-February 2020. EID. 2020;26(6).

7. Novel CPERE. The epidemiological characteristics of an outbreak of 2019 novel coronavirus diseases (COVID-19) in China. Zhonghua liu xing bing xue za zhi= Zhonghua liuxingbingxue zazhi. 2020;41(2):145.

8. WHO. Report of the WHO-China Joint Mission on Coronavirus Disease 2019 (COVID19). February; 2020.

9. Rodriguez-Morales AJ, Cardona-Ospina JA, Gutiérrez-Ocampo E, Villamizar-Peña R, Holguin-Rivera Y, Escalera-Antezana JP, et al. Clinical, laboratory and imaging features of COVID-19: A systematic review and meta-analysis. Travel Med. Infect. Dis. 2020:101623.

10. The world fact book: Europe- Italy 2020 [03/25/2020]. Available from: https://www.cia.gov/library/publications/the-world-factbook/geos/print it.html 11. WHO. Coronavirus disease 2019 (COVID-19): Situation reports 11-111. 2020. 
medRxiv preprint doi: https://doi.org/10.1101/2020.04.01.20049668; this version posted May 18, 2020. The copyright holder for this preprint (which was not certified by peer review) is the author/funder, who has granted medRxiv a license to display the preprint in perpetuity.

It is made available under a CC-BY-NC-ND 4.0 International license .

312 12. Ministry of Health Italy. New Coronavirus Italy: Ministry of Health; 2020. Available 313 from:

314 http://www.salute.gov.it/portale/nuovocoronavirus/archivioNotizieNuovoCoronavirus.jsp

315 13. Nishiura H, Klinkenberg D, Roberts M, Heesterbeek JA. Early epidemiological

316 assessment of the virulence of emerging infectious diseases: a case study of an influenza

317 pandemic. PLoS One. 2009;4(8).

318 14. Tsuzuki S, Lee H, Miura F, Chan YH, Jung S-m, Akhmetzhanov AR, et al. Dynamics of 319 the pneumonic plague epidemic in Madagascar, August to October 2017. Euro Surveill. $320 \quad 2017 ; 22(46)$

321 15. Gamerman D, Lopes HF. Markov chain Monte Carlo: stochastic simulation for Bayesian 322 inference: CRC Press; 2006.

323 16. Gelman A, Rubin DB. Inference from iterative simulation using multiple sequences. Stat 324 Sci. 1992;7(4):457-72.

325 17. Shim Eunha, Mizumoto Kenji, Choi Wongyeong, Chowell Gerardo. Estimating the risk 326 of COVID-19 death during the course of the outbreak in Korea, February- March, 2020.

3272020.

328 18. Onder G, Rezza G, Brusaferro S. Case-Fatality Rate and Characteristics of Patients Dying 329 in Relation to COVID-19 in Italy. JAMA. 2020.

330 19. statistica. Population of China in 2019, by broad age group 2019. Available from:

331 https://www.statista.com/statistics/251524/population-distribution-by-age-group-in-china/

332 20. Taylor DB. How the Coronavirus Pandemic Unfolded: a Timeline. The New York Times.

333 May 12, 2020. Available from: https://www.nytimes.com/article/coronavirus-

$334 \quad$ timeline.html

335 21. McCann A, Popovich N, Wu J. Italy’s Virus Shutdown Came Too Late. What Happens

336 Now? The New York Times. April 5, 2020. Available from: 
medRxiv preprint doi: https://doi.org/10.1101/2020.04.01.20049668; this version posted May 18, 2020. The copyright holder for this preprint (which was not certified by peer review) is the author/funder, who has granted medRxiv a license to display the preprint in perpetuity.

It is made available under a CC-BY-NC-ND 4.0 International license .

https://www.nytimes.com/interactive/2020/04/05/world/europe/italy-coronaviruslockdown-reopen.html

22. Mizumoto K, Endo A, Chowell G, Miyamatsu Y, Saitoh M, Nishiura H. Real-time

340 characterization of risks of death associated with the Middle East respiratory syndrome

341 (MERS) in the Republic of Korea, 2015. BMC med. 2015;13(1):228.

342 23. Yang S, Cao P, Du P, Wu Z, Zhuang Z, Yang L, et al. Early estimation of the case fatality

343 rate of COVID-19 in mainland China: a data-driven analysis. Ann Transl Med. 2020;8(4).

344 24. Feuer W, Kim J. WHO warns that coronavirus cases have jumped in countries that eased

345 lockdowns. CNBC. May 11, 2020. Available from:

346 https://www.cnbc.com/2020/05/11/who-warns-that-coronavirus-cases-have-jumped-in-

$347 \quad$ countries-that-eased-lockdowns.html

348 25. Lipsitch M, Donnelly CA, Fraser C, Blake IM, Cori A, Dorigatti I, et al. Potential biases

349 in estimating absolute and relative case-fatality risks during outbreaks. PLoS Neglect

$350 \quad$ Trop D. 2015;9(7).

351 26. Yu H, Cowling BJ, Feng L, Lau EH, Liao Q, Tsang TK, et al. Human infection with

352 avian influenza A H7N9 virus: an assessment of clinical severity. Lancet.

$353 \quad$ 2013;382(9887):138-45.

354 27. Cauchemez S, Fraser C, Van Kerkhove MD, Donnelly CA, Riley S, Rambaut A, et al.

355 Middle East respiratory syndrome coronavirus: quantification of the extent of the

356 epidemic, surveillance biases, and transmissibility. Lancet Infect Dis. 2014;14(1):50-6.

357 28. Kucharski AJ, Edmunds WJ. Case fatality rate for Ebola virus disease in west Africa.

$358 \quad$ Lancet. 2014;384(9950):1260. 
medRxiv preprint doi: https://doi.org/10.1101/2020.04.01.20049668; this version posted May 18, 2020. The copyright holder for this preprint (which was not certified by peer review) is the author/funder, who has granted medRxiv a license to display the preprint in perpetuity.

It is made available under a CC-BY-NC-ND 4.0 International license .

361 Table 1. Summary results of time-delay adjusted case fatality ratio of COVID-19 by

362 region in Italy, 2020 (As of May 10, 2020)

\begin{tabular}{|c|c|c|c|}
\hline Area & Latest estimate & $\begin{array}{l}\text { Range of median estimates } \\
\text { during the study period }\end{array}$ & Crude CFR \\
\hline Lombardia & $24.7 \%\left(95 \% \mathrm{CrI}^{\S}: 24.4-25.1 \%\right)$ & $21.4-99.5 \%$ & $\begin{array}{c}18.4 \%\left(95 \% \mathrm{CI}^{\mathrm{I}}: 18.1-18.7 \%\right) \\
14986 / 81507\end{array}$ \\
\hline Emilia Romagna & $17.7 \%$ (95\% CrI: 17.2-18.3\%) & $16.1-97.7 \%$ & $\begin{array}{c}14.3 \% \text { (95\% CI: } 13.9-14.8 \%) \\
3845 / 26796\end{array}$ \\
\hline Veneto & $10.8 \%$ (95\%CrI: $10.3-11.3 \%)$ & $8.6-93.4 \%$ & $\begin{array}{c}8.9 \% \text { (95\%CI: } 8.4-9.3 \%) \\
1657 / 18722\end{array}$ \\
\hline Piemonte & $13.6 \%$ (95\% CrI: $13.2-14.0 \%)$ & $13.6-84.3 \%$ & $\begin{array}{c}11.7 \% \text { (95\%CI: } 11.4-12.1 \%) \\
3367 / 28665\end{array}$ \\
\hline Marche & $19.3 \%$ (95\%CrI: $18.2-20.5 \%)$ & $16.0-86.6 \%$ & $\begin{array}{c}14.7 \% \text { (95\% CI: } 13.8-15.6 \%) \\
960 / 6533\end{array}$ \\
\hline Toscana & $10.4 \%$ (95\% CrI: $9.7-11.0 \%)$ & $5.8-5.15 \%$ & $\begin{array}{c}9.6 \% \text { (95\% CI: } 9.1-10.2 \%) \\
942 / 9774\end{array}$ \\
\hline Lazio & $9.1 \%$ (95\% CrI: $8.3-9.8 \%$ ) & $7.3-64.1 \%$ & $\begin{array}{c}7.8 \% \text { (95\% CI: } 7.2-8.4 \%) \\
557 / 7165\end{array}$ \\
\hline Campania & $9.0 \%$ (95\% CrI: $8.1-9.9 \%)$ & $7.5-50.6 \%$ & $\begin{array}{c}8.5 \% \text { (95\% CI: } 7.7-8.7 \%) \\
391 / 4588\end{array}$ \\
\hline Liguria & $17.6 \%$ (95\% CrI: $16.8-18.6 \%)$ & $17.3-89.9 \%$ & $\begin{array}{c}14.6 \% \text { (95\% CI: } 13.8-15.3 \%) \\
1281 / 8788\end{array}$ \\
\hline Friuli V.G. & $11.2 \%$ (95\%CrI: $10.0-12.4 \%)$ & $10.1-63.2 \%$ & $\begin{array}{c}9.9 \% \text { (95\% CI: } 8.9-11.0 \%) \\
310 / 3130\end{array}$ \\
\hline Sicilia & $8.6 \%$ (95\% CrI: 7.6-9.6\%) & $5.0-51.2 \%$ & $\begin{array}{c}\text { 7.7\% (95\%CI: } 6.8-8.7 \%) \\
\text { 256/3327 }\end{array}$ \\
\hline Puglia & $11.8 \%$ (95\%CrI: 10.9-12.8\%) & $11.6-79.8 \%$ & $\begin{array}{c}10.4 \% \text { (95\% CI: } 9.5-11.3 \%) \\
448 / 4313\end{array}$ \\
\hline Umbria & $5.2 \%$ (95\% CrI: $4.0-6.4 \%)$ & $4.6-51.6 \%$ & $\begin{array}{c}5.0 \% \text { (95\% CI: } 4.0-6.3 \%) \\
71 / 1411\end{array}$ \\
\hline Molise & $8.2 \%$ (95\% CrI: $5.2-11.8 \%)$ & $7.5-51.2 \%$ & $\begin{array}{c}5.9 \% \text { (95\% CI: } 3.8-8.9 \%) \\
22 / 370\end{array}$ \\
\hline Trento & $11.7 \%$ (95\% CrI: $10.7-12.8 \%)$ & $10.0-52.2 \%$ & $\begin{array}{c}10.3 \% \text { (95\% CI: 9.4-11.2\%) } \\
441 / 4295\end{array}$ \\
\hline Abruzzo & $12.3 \%$ (95\%CrI: $11.1-13.5 \%)$ & $12.3-59.3 \%$ & $\begin{array}{c}11.6 \% \text { (95\% CI: } 10.5-12.7 \%) \\
359 / 3103\end{array}$ \\
\hline Bolzano & $11.8 \%$ (95\%CrI: $10.6-13.1 \%)$ & $11.8-53.3 \%$ & $\begin{array}{c}11.3 \% \text { (95\%CI: } 10.1-12.6 \%) \\
290 / 2569\end{array}$ \\
\hline Valle d'Aosta & $13.7 \%$ (95\%CrI: $11.7-15.8 \%)$ & $12.9-54.2 \%$ & $\begin{array}{c}12.0 \% \text { (95\% CI: } 10.2-14.0 \%) \\
139 / 1157\end{array}$ \\
\hline Sardegna & $9.7 \%$ (95\% CrI: $8.1-11.5 \%)$ & $7.0-51.5 \%$ & $\begin{array}{c}9.0 \% \text { (95\% CI: } 7.5-10.6 \%) \\
120 / 1340\end{array}$ \\
\hline Calabria & $8.4 \%$ (95\% CrI: $6.8-10.2 \%)$ & $8.2-51.7 \%$ & $\begin{array}{c}8.0 \% \text { (95\% CI: } 6.5-9.8 \%) \\
91 / 1132\end{array}$ \\
\hline Basilicata & $8.1 \%$ (95\% CrI: $5.3-11.5 \%)$ & $5.3-53.2 \%$ & $\begin{array}{c}7.0 \% \text { (95\% CI: } 4.7-10.0 \%) \\
27 / 385\end{array}$ \\
\hline Italy (National) & $17.4 \%$ (95\%CrI: $17.2-17.6 \%)$ & $15.9-99.6 \%$ & $\begin{array}{c}13.9 \% \text { (95\% CI: } 13.8-14.1 \%) \\
30560 / 219070\end{array}$ \\
\hline
\end{tabular}

363

${ }^{\S} \mathrm{CrI}: 95 \%$ credibility intervals $(\mathrm{CrI}),{ }^{\mathrm{q}} 95 \% \mathrm{CI}: 95 \%$ confidence interval 
medRxiv preprint doi: https://doi.org/10.1101/2020.04.01.20049668; this version posted May 18, 2020. The copyright holder for this preprint (which was not certified by peer review) is the author/funder, who has granted medRxiv a license to display the preprint in perpetuity.

It is made available under a CC-BY-NC-ND 4.0 International license .

367 Figure legend

368 Figure 1: Temporal distribution of cases by region due to COVID-19, Italy, March-May

3692020.

370 Cumulative cases in (A) Lombardia, (B) Emilia Romagna, (C) Veneto, (D) Piemonte, (E)

371 Marche, (F) Toscana, (G) Lazio, (H) Campania, (I) Liguria, (J) Friuli V.G., (K) Sicilia, (L)

372 Puglia, (M) Umbria, (N) Molise, (O) Trento, (P) Abruzzo, (Q) Bolzano, (R) Valle d'Aosta,

373 (S) Sardegna, (T) Calabria, (U) Basilicata, and (V) National over time. Day 1 corresponds to

374 March 1st in 2020. As the dates of illness onset were not available, we used dates of reporting.

375

376 Figure 2: Temporal distribution of deaths by region due to COVID-19, Italy, March-

377 May 2020.

378 Cumulative death in (A) Lombardia, (B) Emilia Romagna, (C) Veneto, (D) Piemonte, (E)

379 Marche, (F) Toscana, (G) Lazio, (H) Campania, (I) Liguria, (J) Friuli V.G., (K) Sicilia, (L)

380 Puglia, (M) Umbria, (N) Molise, (O) Trento, (P) Abruzzo, (Q) Bolzano, (R) Valle d'Aosta,

381 (S) Sardegna, (T) Calabria, (U) Basilicata, and (V) National over time. Day 1 corresponds to

382 March 1st in 2020.

383

384 Figure 3: Temporal variation of risk of death caused by COVID-19 by region, Italy,

385 March-May 2020: crude case fatality ratio (cCFR)

386 Observed and posterior estimated of crude case fatality ratio in (A) Lombardia, (B) Emilia

387 Romagna, (C) Veneto, (D) Piemonte, (E) Marche, (F) Toscana, (G) Lazio, (H) Campania, (I)

388 Liguria, (J) Friuli V.G., (K) Sicilia, (L) Puglia, (M) Umbria, (N) Molise, (O) Trento, (P)

389 Abruzzo, (Q) Bolzano, (R) Valle d'Aosta, (S) Sardegna, (T) Calabria, (U) Basilicata, and (V)

390 National. Day 1 corresponds to March 1st in 2020. Black dots show crude case fatality ratio,

391 and light and dark indicates $95 \%$ and 50\% credible intervals for posterior estimates,

392 respectively. 
medRxiv preprint doi: https://doi.org/10.1101/2020.04.01.20049668; this version posted May 18, 2020. The copyright holder for this preprint (which was not certified by peer review) is the author/funder, who has granted medRxiv a license to display the preprint in perpetuity.

It is made available under a CC-BY-NC-ND 4.0 International license .

395 Figure 4: Temporal variation of risk of death caused by COVID-19 by region, Italy,

396 March-May 2020: time-delay adjusted case fatality ratio (aCFR)

397 Observed and posterior estimated of time-delay adjusted case fatality ratio in (A) Lombardia,

398 (B) Emilia Romagna, (C) Veneto, (D) Piemonte, (E) Marche, (F) Toscana, (G) Lazio, (H)

399 Campania, (I) Liguria, (J) Friuli V.G., (K) Sicilia, (L) Puglia, (M) Umbria, (N) Molise, (O)

400 Trento, (P) Abruzzo, (Q) Bolzano, (R) Valle d'Aosta, (S) Sardegna, (T) Calabria, (U)

401 Basilicata, and (V) National. Day 1 corresponds to March 1st in 2020. Black dots show crude

402 case fatality ratio, and light and dark indicates $95 \%$ and $50 \%$ credible intervals for posterior

403 estimates, respectively.

404

405 Figure 5. Latest estimates of time-delay adjusted risk of death caused by COVID-19 by

406 region, 2020, Italy.

407 Distribution of time-delay adjusted case fatality risks derived from the latest estimates (May

408 10, 2020) are presented. Top to bottom: Lombardia, Emilia Romagna, Veneto, Piemonte,

409 Marche, Toscana, Lazio, Campania, Liguria, Friuli V.G., Sicilia, Puglia, Umbria, Molise,

410 Trento, Abruzzo, Bolzano, Valle d'Aosta, Sardegna, Calabria, Basilicata and National

411

412

413

Figure 6. Geographical variability of COVID-19 time-delay adjusted CFR, population density, and cumulative morbidity rate across 20 regions in Italy

414 Distribution of time-delay adjusted case fatality risks derived from the latest estimates (May

$41510,2020)$ are presented. Top to $\mathrm{b}(\mathrm{A})$ time -delay adjusted case fatality rate (B)Population

416 density per square $\mathrm{km}$ (2019) (C) Cumulative morbidity rate in percent 


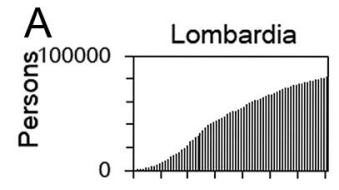

0 10203040506070

$\mathrm{F}$

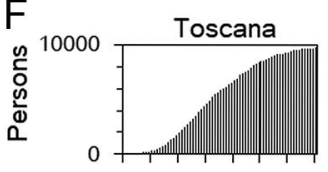

0 10203040506070

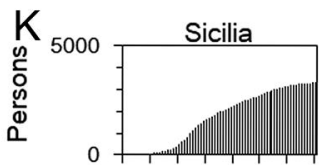

0 10203040506070

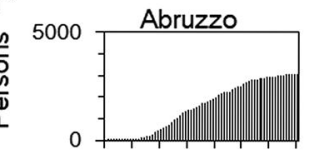

0 10203040506070

1
on
0
0
0

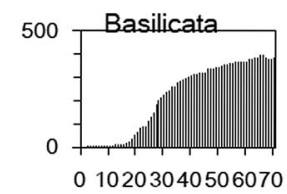

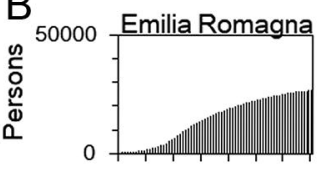

0 10203040506070

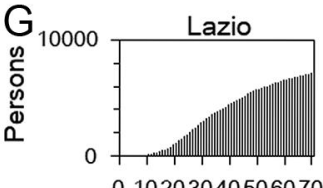

o 10203040506070
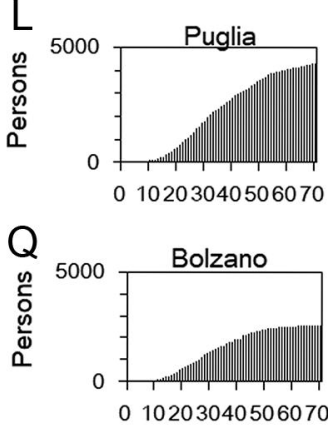

V

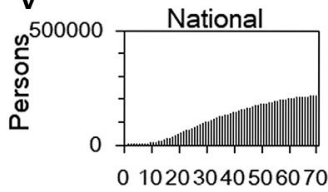

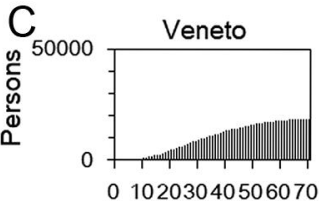

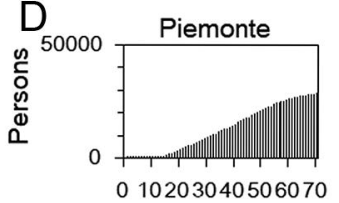

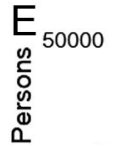

Marche
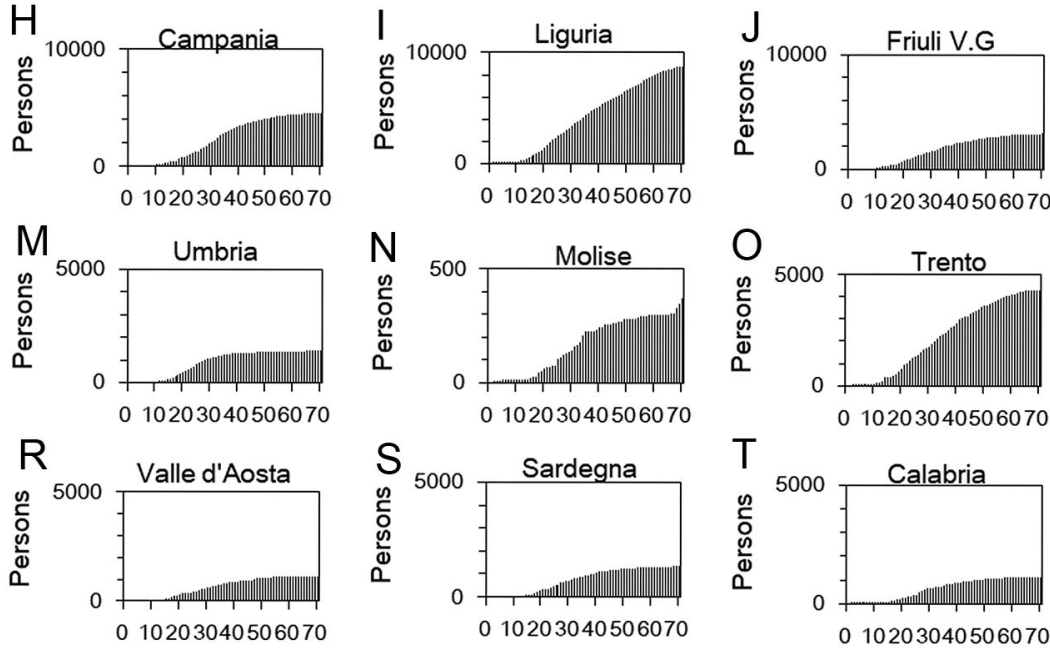

o 10203040506070

010203040506070 


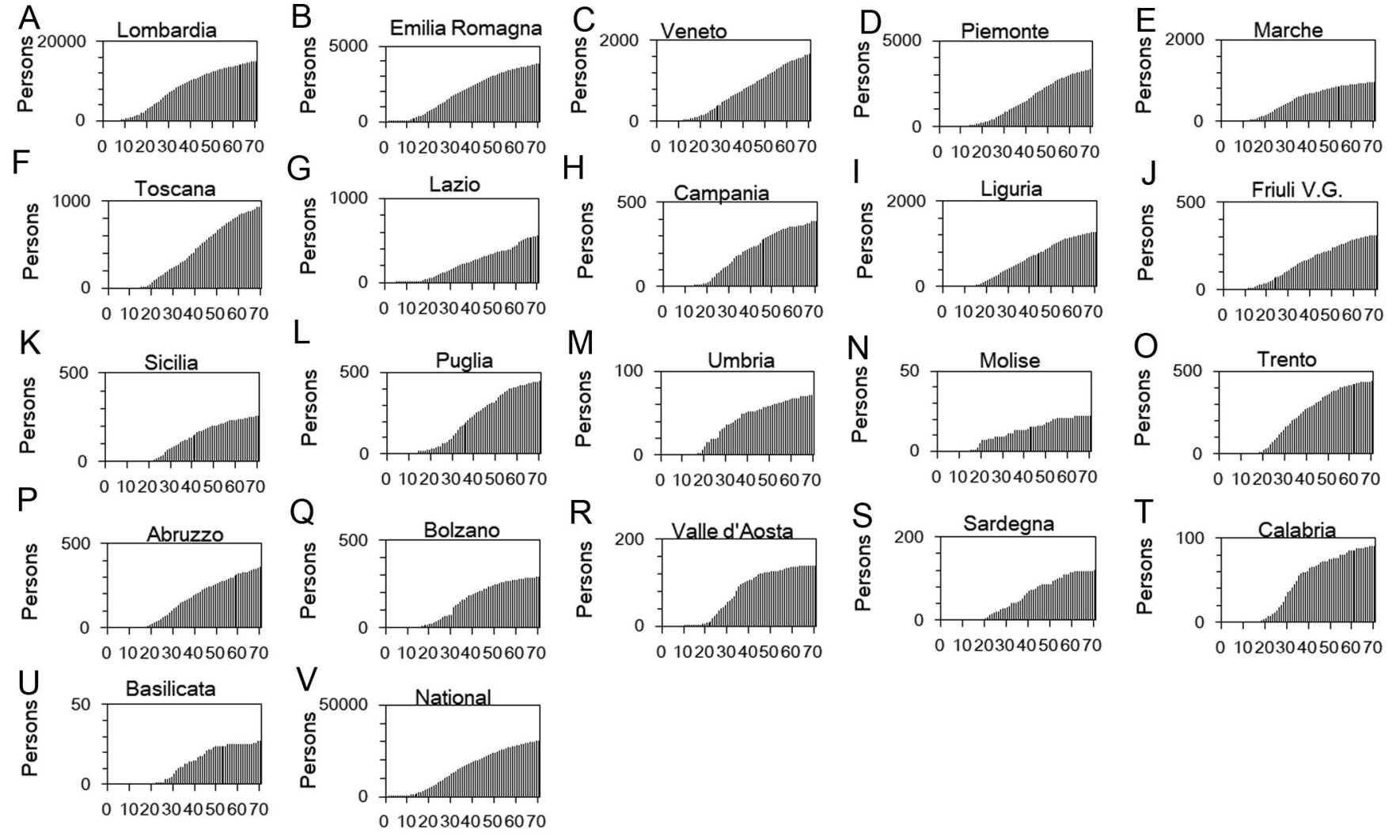


Time delay adjusted CFR by region The latest estimate

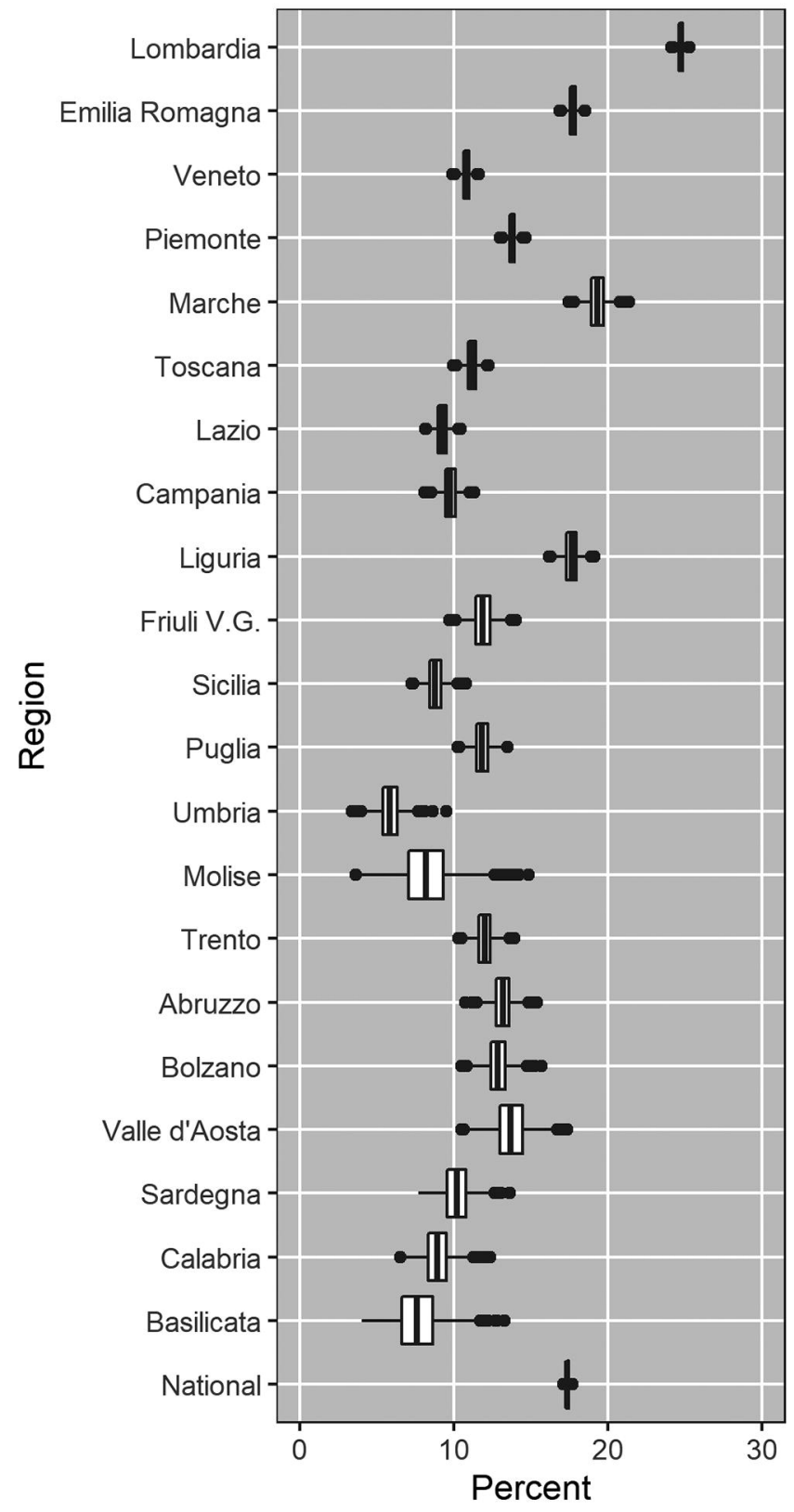


A

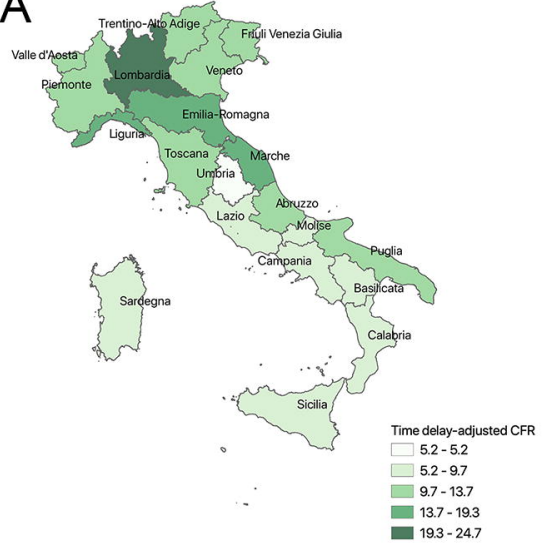

B

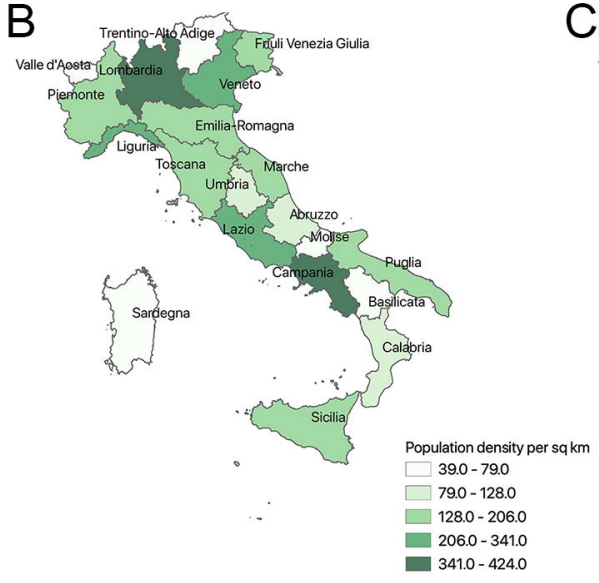

C
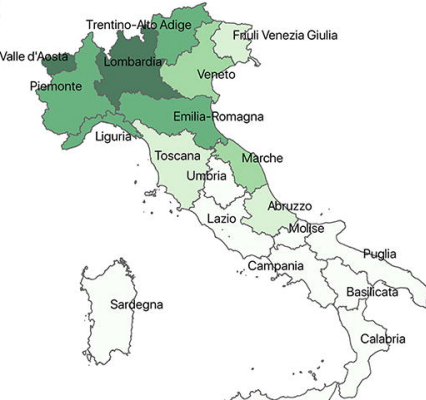

Cumulative morbidity rate $\square$ 0.06- 0.16 $\square 0.16-0.26$ $\square .26-0.43$ $0.43-0.66$ $0.66-0.92$ 